\title{
Estimates of genetic parameters for fat yield in Murrah buffaloes
}

\author{
Manoj Kumar ${ }^{1}$, Vikas Vohra², Poonam Ratwan ${ }^{1}$, Jamuna Valsalan ${ }^{1}$, C. S. Patil ${ }^{3}$ and A. K. Chakravarty ${ }^{1}$
}

1. Division of Dairy Cattle Breeding, ICAR-National Dairy Research Institute, Karnal - 132001 , Haryana, India; 2. Department of Animal Genetic Resources, ICAR-National Bureau of Animal Genetic Resources, Karnal - 132 001 , Haryana, India; 3. Department of Animal Genetics and Breeding, Lala Lajpat Rai University of Veterinary \& Animal Sciences, Hisar, Haryana, India.

Corresponding author: Vikas Vohra, e-mail: vohravikas@gmail.com, MK: drmanojneemwal@gmail.com, PR: punam.ratwan@gmail.com, JV: jamunavalsalan@gmail.com, CSP: dr.cspatil03@gmail.com, AKC: ak_chakravarty@yahoo.co.in

Received: 26-08-2015, Revised: 22-01-2016, Accepted: 03-02-2016, Published online: 19-03-2016

doi: 10.14202/vetworld.2016.295-298 How to cite this article: Kumar M, Vohra V, Ratwan P, Valsalan J, Patil CS, Chakravarty AK (2016) Estimates of genetic parameters for fat yield in Murrah buffaloes, Veterinary World, 9(3): 295-298.

\begin{abstract}
Aim: The present study was performed to investigate the effect of genetic and non-genetic factors affecting milk fat yield and to estimate genetic parameters of monthly test day fat yields (MTDFY) and lactation 305-day fat yield (L305FY) in Murrah buffaloes.

Materials and Methods: The data on total of 10381 MTDFY records comprising the first four lactations of 470 Murrah buffaloes calved from 1993 to 2014 were assessed. These buffaloes were sired by 75 bulls maintained in an organized farm at ICAR-National Dairy Research Institute, Karnal. Least squares maximum likelihood program was used to estimate genetic and non-genetic parameters. Heritability estimates were obtained using paternal half-sib correlation method. Genetic and phenotypic correlations among MTDFY, and 305-day fat yield were calculated from the analysis of variance and covariance matrix among sire groups.
\end{abstract}

Results: The overall least squares mean of L305FY was found to be $175.74 \pm 4.12 \mathrm{~kg}$. The least squares mean of overall MTDFY ranged from $3.33 \pm 0.14 \mathrm{~kg}$ (TD-11) to $7.06 \pm 0.17 \mathrm{~kg}$ (TD-3). The $\mathrm{h}^{2}$ estimate of L305FY was found to be $0.33 \pm 0.16$ in this study. The estimates of phenotypic and genetic correlations between 305-day fat yield and different MTDFY ranged from 0.32 to 0.48 and 0.51 to 0.99 , respectively.

Conclusions: In this study, all the genetic and non-genetic factors except age at the first calving group, significantly affected the traits under study. The estimates of phenotypic and genetic correlations of MTDFY with 305-day fat yield was generally higher in the MTDFY-5 of lactation suggesting that this TD yields could be used as the selection criteria for early evaluation and selection of Murrah buffaloes.

Keywords: genetic factors, Murrah buffalo, non-genetic factors, test-day fat yields.

\section{Introduction}

India has about 51 million milch buffaloes [1] contributing about $51 \%$ [2] of the total milk produced in the country. Compared with cow's milk, buffalo's milk has a higher percentage of fat percentage. The reported values of fat percentage for buffalo's milk varies from $6.87 \%$ to $8.59 \%[3,4]$. In spite of its higher fat percentage, milk cholesterol content is lower in buffalo's milk compared to cow's milk, which is $275 \mathrm{mg}$ versus $330 \mathrm{mg}$ as reported by Zicarelli [5]. Milk fat plays a significant role in the nutritive value and physical properties of milk and milk products. Besides serving as a rich source of energy, fat contains significant amounts of essential fatty acids-linolenic and arachidonic acid. The most distinctive role which milk fat plays in dairy products concerns flavor.

\footnotetext{
Copyright: Kumar, et al. Open Access. This article is distributed under the terms of the Creative Commons Attribution 4.0 International License (http://creativecommons.org/licenses/by/4.0/), which permits unrestricted use, distribution, and reproduction in any medium, provided you give appropriate credit to the original author(s) and the source, provide a link to the Creative Commons license, and indicate if changes were made. The Creative Commons Public Domain Dedication waiver (http://creativecommons.org/ publicdomain/zero/1.0/) applies to the data made available in this article, unless otherwise stated.
}

Nowadays, milk pricing system is also based on the percentage of fat in milk, therefore, higher milk fat yield fetches better economic returns. Murrah is the most important buffalo breed with superior genetic potential for milk fat yield production.

To find out an alternative to daily milk yield recording, which is a costly and time-consuming proposition under field conditions, some studies have been made in the past in buffaloes on test day (TD) milk yields [6,7]. Various advantages of using TD milk yield records are individual test date effects, and the number of records per animal as well as the interval between records can be accounted for better adjustment of non-genetic factors influencing the milk yield leading to more accurate genetic evaluation. Today, in many countries across the continents, multi trait evaluations are employed in genetic evaluations. TD milk fat yield records can be used in combination for more accurate genetic evaluation. Although TD fat yield records offer greater advantage compared to 305-day fat yield in selection schemes, information on estimation of genetic parameters based on TD records particularly, monthly records are limited. 
The present investigation was undertaken with the objective to study the influence of various non-genetic and genetic factors on monthly TD and lactation 305-day fat yields (L305FY) and to estimate the genetic parameters for milk fat yield, which could be used for selecting Murrah buffaloes for higher fat yield.

\section{Materials and Methods}

\section{Ethical approval}

The experiment was conducted following the code of ethics for animal experimentation with approval from the Institute's Animal Ethics Committee.

\section{Data}

A total of 10381 monthly TD fat yield (MTDFY) records comprised first four lactations of 470 Murrah buffaloes calved during 1993-2014 at the ICARNational Dairy Research Institute, Karnal were collected from the history-cum-pedigree sheets and monthly record of milk yield and fat percentage register. The traits considered for analysis were MTDFY and L305FY. Culling in the middle of lactation, abortion, stillbirth, or any other pathological causes affecting the lactation yield were considered as abnormalities and thus, such records were not taken for the study. Records of buffaloes with $<500 \mathrm{~kg}$ of milk production and covered $<100$ days of lactation, were not considered, a set practice at our herd, as usually such animals had shown good average daily milk yield. To ensure the normal distribution, the outliers $(\mu \pm 3$ standard deviation) were removed, and data set was standardized. The data were analyzed to study the effect of non-genetic factors (parity, season, period and age at first calving $[\mathrm{AFC}]$ groups) on 11 MTDFY records (from $6^{\text {th }}, 36^{\text {th }}$, $66^{\text {th }}$, and $300^{\text {th }}$ day of lactation) and L305FY records. The data were classified into different seasons, periods and AFC groups. Each year was classified into four seasons on the basis of rainfall, temperature and humidity over the years-winter (December-March), summer (April-June), rainy (July-August), and autumn (September-November). The data spread over 22 years were classified into 10 periods. The data were classified into 9 AFC sub-groups using Sturges' formula [8]. Fat percentage was determined by Lacto Star apparatus (German equipment produced by Funke-Gerber). For calibration of Lacto Star apparatus, fat percentage of milk was tested by Gerber method [9].

\section{Statistical methods}

The least squares maximum likelihood program of Harvey [10] was used to estimate and study the effect of genetic and non-genetic factors on MTDFY and L305FY records of Murrah buffaloes:

$$
\mathrm{Y}_{\mathrm{ijklmn}}=\mu+\mathrm{PA}_{\mathrm{i}}+\mathrm{S}_{\mathrm{j}}+\mathrm{P}_{\mathrm{k}}+\mathrm{A}_{1}+\mathrm{B}_{\mathrm{m}}+\mathrm{e}_{\mathrm{ij} \mathrm{jlmn}}
$$

Where, $Y_{i j \mathrm{jkm}}=$ Observation on the $\mathrm{n}^{\text {th }}$ individual in $\mathrm{i}^{\text {th }}$ parity, $\mathrm{j}^{\text {th }}$ seasmn $\mathrm{k}^{\text {th }}$ period, $\mathrm{l}^{\text {th }} \mathrm{AFC}$ group and sired by $\mathrm{m}^{\text {th }}$ bull, $\mu=$ Overall population mean, $\mathrm{PA}_{\mathrm{i}}=$ Effect of $i^{\text {th }}$ parity (1-4), $S_{j}=$ Effect of $j^{\text {th }}$ season (1-4) four seasons: Winter (December to March), summer (April to June), rainy (July to August), autumn
(September to November) were considered for analysis, $P_{k}=$ Fixed effect of $k^{\text {th }}$ period of study (1-10) a period in a block of 2 years was considered, $A_{1}=$ Fixed effect of $1^{\text {th }}$ AFC group, $B_{m}=$ Random effect of $m^{\text {th }}$ bull (sire), $\mathrm{e}_{\mathrm{ijk} k m n}=$ Random error, $\operatorname{NID}\left(0, \sigma_{\mathrm{e}}^{2}\right)$.

\section{Estimation of heritability}

Paternal half-sib correlation method given by Becker, 1975 [11] was used to estimate the heritability of different characters and their genetic correlations. A total of 75 bulls having three or more number of progeny were included for the estimation of heritability. The data were adjusted for those non-genetic factors showing significant effects and further used for estimation of heritability. The standard error of heritability was estimated as per Swiger et al. [12].

\section{Genetic and phenotypic correlations}

The genetic and phenotypic correlations among MTDFY and 305-days fat yield were calculated from the analysis of variance and covariance among sire groups as given by Becker [11] and shown in below.

$$
\mathrm{r}_{\mathrm{g}(\mathrm{XY})}=\operatorname{Cov~S}_{\mathrm{xy}} / \sqrt{ } \sigma_{\mathrm{s}(\mathrm{x})}^{2} \cdot \sigma_{\mathrm{s}(\mathrm{y})}^{2}
$$

\section{Results and Discussion}

The least squares mean along with their standard errors for MTDFY and L305FY are shown in Table-1. The highest MTDFY was observed in MTDFY-3 $(7.06 \mathrm{~kg})$, and the lowest was observed in MTDFY-11 (3.33 kg). In general, MTDFY increased until MTDFY-3 and thereafter a gradual decline was noticed until the end of lactation. The overall mean of average 305-day fat yield was $175.74 \pm 4.12 \mathrm{~kg}$. Ibrahim et al. [13] and Tonhati et al. [14] reported overall mean of 305-day fat yield as $147.67 \mathrm{~kg}$ and $90.1 \mathrm{~kg}$ in Egyptian buffaloes and Murrah buffaloes herd in Sao population, respectively, which was comparatively lower than Murrah breed in this study.

\section{Effect of non-genetic factors}

\section{Parity}

The effect of parity was highly significant ( $<<0.01$ ) up to MTDFY-6 and L305FY; non-significant

Table-1: Least squares means of L305FY and different MTDFY (in kg).

\begin{tabular}{lccc}
\hline Trait & $\mathbf{N}$ & Mean \pm SE & CV (\%) \\
\hline MTDFY1 & 1049 & $6.81 \pm 0.184$ & 39.44 \\
MTDFY2 & 1049 & $7.05 \pm 0.18$ & 33.41 \\
MTDFY3 & 1049 & $7.06 \pm 0.17$ & 31.72 \\
MTDFY4 & 1049 & $6.55 \pm 0.14$ & 31.34 \\
MTDFY5 & 1048 & $6.11 \pm 0.13$ & 33.12 \\
MTDFY6 & 1028 & $5.56 \pm 0.16$ & 34.33 \\
MTDFY7 & 1002 & $5.15 \pm 0.17$ & 36.80 \\
MTDFY8 & 949 & $4.56 \pm 016$ & 38.42 \\
MTDFY9 & 869 & $4.73 \pm 0.13$ & 42.76 \\
MTDFY10 & 722 & $3.74 \pm 0.15$ & 44.01 \\
MTDFY11 & 567 & $3.33 \pm 0.14$ & 48.09 \\
L305FY & 1049 & $175.74 \pm 4.12$ & 26.55 \\
\hline
\end{tabular}

$\mathrm{N}=$ Number of observation, $\mathrm{L} 305 \mathrm{FY}=$ Lactation 305-fat yield, MTDFY=Monthly test day fat yields, $S E=$ Standard error, $\mathrm{CV}=$ Coefficient of variation in percentage 
Table-2: Mixed model ANOVA showing mean sum of squares for factors affecting MTDFY and L305FY.

\begin{tabular}{|c|c|c|c|c|c|c|}
\hline Traits & Sire & Parity & Season & Period & AFC group & Error \\
\hline d.f. & 74 & 3 & 3 & 9 & 8 & 951 \\
\hline MTDFY1 & $7.38 *$ & $154.86 * *$ & $22.90 * *$ & $11.56 *$ & $7.67^{\mathrm{NS}}$ & 5.37 \\
\hline MTDFY2 & $6.88 * *$ & $85.91 * *$ & $30.84 * *$ & $10.91 *$ & $9.97 *$ & 4.625 \\
\hline MTDFY3 & $6.19 * *$ & $70.12 * *$ & $40.11^{* *}$ & $8.05 *$ & $11.69 * *$ & 4.03 \\
\hline MTDFY4 & $4.80^{\mathrm{NS}}$ & $35.96 * *$ & $2.78^{\mathrm{NS}}$ & $6.18^{\mathrm{NS}}$ & $7.16^{\mathrm{NS}}$ & 3.86 \\
\hline MTDFY5 & $4.51^{\mathrm{NS}}$ & $28.21^{* *}$ & $3.54^{\mathrm{NS}}$ & $8.90 *$ & $9.19 *$ & 3.66 \\
\hline MTDFY6 & $5.91 * *$ & $23.46 * *$ & $6.47^{\mathrm{NS}}$ & $6.85^{\mathrm{NS}}$ & 7.99* & 3.93 \\
\hline MTDFY7 & $6.46 * *$ & $9.97^{\mathrm{NS}}$ & $9.48^{\mathrm{NS}}$ & $9.11 *$ & $4.47^{\mathrm{NS}}$ & 4.36 \\
\hline MTDFY8 & $5.83 *$ & $3.60^{\mathrm{NS}}$ & $15.24 *$ & $7.97^{\mathrm{NS}}$ & $4.51^{\mathrm{NS}}$ & 4.35 \\
\hline MTDFY9 & $4.93^{\mathrm{NS}}$ & $7.99^{\mathrm{NS}}$ & $19.435^{* *}$ & $10.58 *$ & $4.87^{\mathrm{NS}}$ & 4.66 \\
\hline MTDFY10 & $5.40^{\mathrm{NS}}$ & $3.06^{\mathrm{NS}}$ & $22.53 * *$ & $11.75 * *$ & $3.06^{\mathrm{NS}}$ & 4.58 \\
\hline MTDFY11 & $4.67^{\mathrm{NS}}$ & $2.98^{\mathrm{NS}}$ & $21.20 * *$ & $11.68 * *$ & $2.55^{\mathrm{NS}}$ & 3.89 \\
\hline L305FY & $3521.85^{* *}$ & $44925.29 * *$ & $16778.69 * *$ & $11805.05^{* *}$ & $1353.61^{\text {NS }}$ & 2301.15 \\
\hline
\end{tabular}

$*_{p} \leq 0.05, * *_{p} \leq 0.01$. NS=Non-significant, L305FY=Lactation 305-fat yield, MTDFY=Monthly test day fat yields, AFC $=$ Age at first calving

effect of parity was observed in rest TD (Table-2). Singh et al. [15] observed the non-significant effect of parity on fat percentage in Murrah buffaloes. Similar results were shown by Shah and Schermerhorn [16] in Nilli-Ravi buffaloes.

\section{Season}

The effect of season of calving was highly significant $(p<0.01)$ up to MTDFY-3 then MTDFY-9 to MTDFY-11 and L305FY; significant $(p<0.05)$ for MTDFY-8. Non-significant effect of season of calving was observed MTDFY-4 to MTDFY-7 (Table-2). Ibrahim et al. [13] and Mourad et al. [17] reported significant effect of season of calving on lactation fat yield in Egyptian buffaloes. Khan et al. [18] also reported a significant effect of season of calving on fat yield in Nilli Ravi buffaloes. In Murrah buffaloes, Hatwar [19] found significant effect of season of calving on fat yield and fat percentages.

\section{Period}

Highly significant effect $(p<0.01)$ of the period of calving was observed for L305FY and MTDFY-10 and MTDFY-11; significant $(\mathrm{p}<0.05)$ for MTDFY-1, MTDFY-2, MTDFY-3, MTDFY-5, MTDFY-7, and MTDFY-9. Non-significant effect of period of calving was observed MTDFY-4, MTDFY-6, and TDFY-8 (Table-2). Ibrahim et al. [13] and Mourad et al. [17] observed significant effect of period of calving on lactation fat yield in Egyptian buffaloes. Khan et al. [18] also found a significant effect of period of calving of fat yield in Nili Ravi buffaloes.

\section{AFC groups}

The effect of AFC groups on MTDFY is presented in Table-2. A significant effect $(p<0.01)$ of the AFC was observed on MTDFY-3; significant $(p<0.05)$ for MTDFY-2, MTDFY-5, MTDFY-6 and rest TD have non-significant effect of AFC groups. Nonsignificant effect of AFC groups was also observed on L305FY. Shah and Schermerhorn [16] reported non-significant effect of AFC on fat percentage in Nilli-Ravi buffaloes.
Table-3: Heritability estimates along with their standard error for L305FY and different MTDFY.

\begin{tabular}{lcclcc}
\hline Trait & $\mathbf{N}$ & $\mathbf{h}^{2} \pm \mathbf{S E}$ & Trait & $\mathbf{N}$ & $\mathbf{h}^{2} \pm$ SE \\
\hline MTDFY1 & 1049 & $0.28 \pm 0.16$ & MTDFY7 & 1002 & $0.29 \pm 0.16$ \\
MTDFY2 & 1049 & $0.37 \pm 0.17$ & MTDFY8 & 949 & $0.06 \pm 0.14$ \\
MTDFY3 & 1049 & $0.43 \pm 0.18$ & MTDFY9 & 869 & $0.22 \pm 0.12$ \\
MTDFY4 & 1049 & $0.30 \pm 0.17$ & MTDFY10 & 722 & $0.18 \pm 0.15$ \\
MTDFY5 & 1048 & $0.41 \pm 0.18$ & MTDFY11 & 567 & $0.13 \pm 0.15$ \\
MTDFY6 & 1028 & $0.40 \pm 0.18$ & L305FY & 1049 & $0.33 \pm 0.16$
\end{tabular}

$\mathrm{N}=$ Number of observation, L305FY=Lactation 305-fat yield, MTDFY=Monthly test day fat yields, $S E=$ Standard error

\section{Genetic and phenotypic parameters}

\section{Heritability}

The heritability of the MTDFY is shown in Table-3. The $\mathrm{h}^{2}$ estimate of MTDFY was the lowest (0.06) for MTDFY-8 and the highest (0.43) for MTDFY-3 and L305FY heritability was 0.33 . Madad et al. [20] observed that heritability estimates ranged from 0.03 to 0.24 for TD fat percentages in Iranian buffaloes. Ibrahim et al. [13] reported heritability of lactation fat yield in Egyptian buffaloes as 0.19. Aspilcueta-Borquis et al. [21] found heritability estimate as 0.23 for L305FY in buffaloes. In Murrah buffaloes, Tonhati et al. [14] observed heritability estimate of lactation fat yield as 0.21 .

\section{Genetic and phenotypic correlations}

The estimates of genetic and phenotypic correlations among 305-day fat yield and MTDFY are shown in Table-4. The estimates of genetic and phenotypic correlations between 305-day fat yield and MTDFY ranged from 0.51 to 0.99 and 0.32 to 0.48 , respectively. Estimate of genotypic and phenotypic correlation between traits was similar to Sahoo et al., 2014 [22]. MTDFY-5 had the highest genetic (0.99) and phenotypic (0.48) correlation with L305FY. Records up to five months can provide the similar results to lactation fat yield with almost 99\% accuracy. Therefore, instead of 11 months with L305FY analysis can be made based on MTDFY-5. 
Table-4: Genetic and phenotypic correlations among L305FY and different MTDFY.

\begin{tabular}{llcc}
\hline Trait 1 & Trait 2 & $\begin{array}{c}\text { Genetic } \\
\text { correlations }\end{array}$ & $\begin{array}{c}\text { Phenotypic } \\
\text { correlations }\end{array}$ \\
\hline L305FY & MTDFY1 & $0.87 \pm 0.28$ & 0.32 \\
& MTDFY2 & $0.63 \pm 0.26$ & 0.39 \\
& MTDFY3 & $0.92 \pm 0.20$ & 0.42 \\
& MTDFY4 & $0.90 \pm 0.30$ & 0.45 \\
& MTDFY5 & $0.99 \pm 0.30$ & 0.48 \\
& MTDFY6 & $0.99 \pm 0.18$ & 0.46 \\
& MTDFY7 & $0.99 \pm 0.19$ & 0.47 \\
& MTDFY8 & $0.88 \pm 0.24$ & 0.46 \\
& MTDFY9 & $0.99 \pm 0.19$ & 0.46 \\
& MTDFY10 & $0.51 \pm 0.41$ & 0.45 \\
& MTDFY11 & $0.73 \pm 0.36$ & 0.43 \\
\hline
\end{tabular}

L305FY=Lactation 305-fat yield, MTDFY=Monthly test day fat yields

\section{Conclusions}

In this study, all the genetic and non-genetic factors except AFC group significantly affected the considered traits. The $\mathrm{h}^{2}$ estimate of lactation milk fat yield was around 0.33 and it ranged from 0.06 (MTDFY-8) to 0.43 (MTDFY-3). The estimates of phenotypic and genetic correlations of monthly TD yields with 305day fat yield were generally higher in MTDFY-5 of lactation suggesting that this $5^{\text {th }}$ TD fat yields could be used as the selection criteria for early evaluation and selection of Murrah buffaloes.

\section{Authors' Contributions}

Research work was done by MK. The experiment was designed and supervised by VV. PR, JV and CSP assisted MK in data recording, literature collection and data analysis, respectively. AKC provided valuable suggestion regarding design of experiment and data analysis. VV and MK compiled the results as well as the manuscript. All authors read and approved the final manuscript.

\section{Acknowledgments}

The authors are thankful to the Director cum Vice Chancellor NDRI \& Director, NBAGR, Karnal (Haryana) for providing the necessary facilities and ICAR for providing financial support. Thanks to In-charge LRC, and In-charge computer center, NDRI for their help.

\section{Competing Interests}

The authors declare that they have no competing interests.

\section{References}

1. $19^{\text {th }}$ Livestock Census. (2012) Available from: http://www. dahd.nic.in/dahd/writeread data/livestock.pdf. Accessed on 05-11-2014.

2. BAHS. (2013) Basic Animal Husbandry Statistics. Department of Animal Husbandry, Dairying and Fisheries. Ministry of Agriculture, Government of India.
3. Rosati, A. and Van Vleck, L.D. (2002) Estimation of genetic parameters for milk, fat, protein and mozzarella cheese production for the Italian river buffalo Bubalus bubalis population. Livest. Prod. Sci., 74: 185-190.

4. Tonhati, H., Vasconcellors, F.B. and Albuquerque, L.G. (2000) Genetic aspects of productive and reproductive traits in a Murrah buffaloes herd in Sao population. J. Anim. Breed Genet., 117: 331-336.

5. Zicarelli, L. (2004) Buffalo milk: Its properties, dairy yield and mozzarella production. Vet. Res. Common., 1(28): 127-135.

6. Chakraborty, D., Dhaka, S.S., Pander, B.L., Yadav, A.S., Singh, S. and Malik, P.K. (2010) Prediction of lactation milk yield from test day records in Murrah buffaloes. Indian J. Anim. Sci., 80(3): 244-245.

7. Singh, S. and Tailor, S.P. (2013) Prediction of 305 days first lactation milk yield from fortnightly test day and part yields. Indian. J. Anim. Sci., 83(2): 166-169.

8. Sturges, H.A. (1926) The choice of a class interval. J. Am. Stat. Assoc., 21(153): 65-66.

9. Indian Standard, IS: 1224 (Part I). (1977) Determination of Fat by Gerber Method. Part I. Milk (First Revision). Indian Standard Institution, Manak Bhavan, New Delhi.

10. Harvey, W.R. (1990) User's Guide for LSMLMW, Mixed Model Least-Squares and Maximum Likelihood Computer Programme. Ohio State University, Columbus, Mimeo.

11. Becker, W.A. (1975) Manual of Quantitative Genetics. $3^{\text {rd }}$ ed. Washington State University, Washington, USA.

12. Swiger, L.A., Harvey, W.R., Everson, D.O. and Gregory, K.E. (1964) The variance of interclass correlation involving group with one observation. Biometrics, 20: 818-826.

13. Ibrahim, M.A., Khattab, A.S., Habaeib, S.E., Awad, S. and Tizser, J. (2012) Genetic parameters for buffalo milk yield and milk quality traits using animal model. AWETH, 8(2): 175-182.

14. Tonhati, H., Ceron, M.F., Oliveira, J.A.M. and El Faro, L. (2008) Test-day milk yield as a selection criterion for dairy buffaloes (Bubalus bubalis Artiodactyla, Bovidae). Genet. Mol. Biol., 31: 674-679.

15. Singh, A., Basu, S.B. and Bathia, K.L. (1979) Milk fat and SNF percentages of Murrah buffaloes. Indian J. Anim. Sci., 32: 446-449.

16. Shah, S.K. and Schermerhorn, E.C. (1983) Factors affecting milk fat percent of Nili-Ravi buffaloes in Pakistan. J. Dairy Sci., 66: 573-577.

17. Mourad, A.K., Mohamed, M.M. and Khattab, A.S. (1991) Genetic parameters for milk production traits in a closed herd of Egyptian buffaloes. Egypt. J. Anim. Prod., 28: 11-20.

18. Khan, M.S., Hassan, F.U., Saif-ur-Rehman, M., Hyder, A.U. and Bajwa, I.R. (2007) Genetic control of milk yield from lactations of different duration in Nili-Ravi buffaloes. Arch. Tierz. Dummerstorf., 50(3): 227-239.

19. Hatwar, R.K. (1986) M.Sc. Thesis, NDRI, Kurukshetra University, Kamal, India.

20. Madad, M., Hossein-Zadeh, N.G., Shadparvar, A.A. and Kianzad, D. (2013) Random regression models to estimate genetic parameters for test-day milk yield and composition in Iranian buffaloes. Arch. Tierz. Dummerstorf., 56(27): 276-284.

21. Aspilcueta-Borquis, R.R., Araujo Neto, F.R., Baldi, F., Bignardi, A.B., Albuquerque, L.G. and Tonhati, H. (2010) Genetic parameters for buffalo milk yield and milk quality traits using Bayesian. J. Dairy Sci., 93: 2195-2201.

22. Sahoo, S.K., Singh, A., Gupta, A.K., Chakravarty, A.K., Singh, M. and Ambhore, G.S. (2014) Estimates of genetic parameters of weekly test day milk yields and first lactation 305 day milk yield in Murrah buffaloes. Vet. World, 7(12): 1094-1098. 